\title{
SIGNIFIKATORY OBLIGATYWNOŚCI W POLSKIM I HISZPAŃSKIM KODEKSIE CYWILNYM
}

\author{
Joanna NOWAK-MICHALSKA, dr \\ Instytut Językoznawstwa, Uniwersytet im. Adama Mickiewicza \\ al. Niepodległości 4, 61-874 Poznań \\ joannanowak@poczta.fm
}

\begin{abstract}
Abstrakt: Artykuł ma na celu przedstawienie i porównanie językowych wykładników jednego ze znaczeń modalności deontycznej, tj. obligatywności (nakazu) w polskim i hiszpańskim kodeksie cywilnym. Na podstawie analizy z tekstów korpusu zostały wyróżnione signifikatory (wykładniki językowe przenoszące znaczenie obligatywności), którymi mogą być wyrazy (podzielone według kategorii partyoratywnej, do której należa) oraz syntagmy. Signifikatorem obligatywności może być również kontekst tekstu normatywnego (tu ustawy). W proponowanym opisie wszystkie signifikatory zostały pogrupowane według kategorii semantycznej wyrazu będącego podmiotem w zdaniu, w którym wystapił dany signifikator. Zaznaczono również, czy dany signifikator występuje w korpusie w czasie teraźniejszym czy przyszłym.
\end{abstract}

\section{THE SIGNIFICATORS OF OBLIGATION IN THE POLISH AND SPANISH CIVIL CODES}

\begin{abstract}
In this paper the significators (i. e. linguistic indicators) of one of the deontic meanings, viz. obligation, in the Polish and Spanish civil codes are presented and compared. The significators of obligation which can be words (classified according to the part of speech they belong to) or syntagms, were identified as a result of an analisis of the corpus. Also, the contex of a normative text (here: statutory instruments) can be the only significator of obligation in a sentence which appeared in such a text. In order to provide a more precise description, the significators are classified according to the semantic category of the word which is the subject of the sentence where the significator appeared. It is also indicated whether a significator is used in the present or future tense.
\end{abstract}

Słowa kluczowe: modalność deontyczna, język prawny, signifikator obligatywności

Modalność deontyczna, jako odnosząca się do nakazu, zakazu, dozwolenia i braku dozwolenia, odgrywa $\mathrm{w}$ języku prawnym ${ }^{1}$ podstawową rolę. Niniejszy artykuł ma na celu przedstawienie i porównanie językowych wykładników jednego ze znaczeń modalnych, tj. obligatywności (nakazu), w polskim i hiszpańskim kodeksie cywilnym². Takie wykładniki językowe przenoszące znaczenia nazywane są signifikatorami (Bańczerowski

\footnotetext{
${ }^{1}$ Przyjmuje się tutaj klasyfikację i nazewnictwo Wróblewskiego, który język prawa dzieli na język prawny (język przepisów prawnych) i prawniczy (język używany przez prawników w odniesieniu do prawa, język doktryny prawniczej) (Wróblewski 1948: 54).

${ }^{2}$ Przedstawiony tu opis to jeden $\mathrm{z}$ rezultatów badań autorki dotyczących modalności deontycznej w polskim i hiszpańskim języku prawnym na przykładzie kodeksów cywilnych. Ich pełne wyniki zawarte są w pracy dostępnej omline (Nowak 2011). Praca ukaże się drukiem w 2013 roku.
} 
2008, 236 i 239). Przedstawione w artykule tabelaryczne zestawienie signifikatorów obligatywności w języku polskim i hiszpańskim, oprócz tego, że daje nam możliwość wglądu w naturę tych języków prawnych, może posłużyć tłumaczom języka prawnego w celu ustalenia ekwiwalentów thumaczeniowych.

Korpusem, na którym oparte są badania są teksty polskiego i hiszpańskiego kodeksu cywilnego. Trzeba jednakże zaznaczyć, że w skład hiszpańskiego kodeksu cywilnego (Código civil, odtąd C.C.) wchodzą regulacje dotyczące prawa rodzinnego i opiekuńczego, które w Polsce zawarte są w osobnym kodeksie (Kodeksie rodzinnym i opiekuńczym). W związku z tym te części C.C. zostały wyłączone z analizy. Są to tytuły (títulos) IV, V, VI, VII, X z Księgi pierwszej (Libro Primero) i Tytuł III z Księgi czwartej (Libro Cuarto). Ilekroć w artykule będzie mowa o C.C., chodzić będzie o tekst C.C. z wyłączeniem tych części.

\section{Kilka uwag o modalności deontycznej}

Modalność deontyczna w języku prawa może być ujmowana z różnych perspektyw prawoznawczej i językoznawczej. Jako że przedmiotem analizy są językowe sposoby wyrażania obligatywności, stosowana jest tutaj perspektywa językoznawcza. Najogólniej mówiąc, modalność deontyczna należy obok modalności epistemicznej i aletycznej do tzw. modalności logicznej. Jest definiowana różnie. Według Lyonsa „dotyczy konieczności lub możliwości aktu dokonywanego przez osobę moralnie odpowiedzialną" (Lyons 1989, II, 409). Rytel z kolei pisze, że modalność ta „wyraża ocenę zdarzenia poprzez stwierdzenie jego obowiązku, zakazu i przyzwolenia" (Rytel 1982, 83). Inni defniują ją jako modalność dotyczącą tego, co jest dobre lub złe według określonego systemu reguł (np. Portner 2009, 15). Za Palmerem w opisie modalności deontycznej można posłużyć się pojęciami „konieczności deontycznej” (,deontic necessity”) i „możliwości deontycznej” (,deontic possibility”). Zarówno konieczność, jak i możliwość może być zaprzeczona (Palmer 1998, 98-99). Zaprzeczenie możliwości to brak możliwości, czyli zakaz, a zaprzeczenie konieczności to brak konieczności. Sa to cztery znaczenia modalności deontycznej, czyli znaczenia deontyczne, które mogą być przenoszone przez zdania. Nazywane są tu odpowiednio:

(i) obligatywnością (konieczność deontyczna, nakaz),

(ii) prohibitywnością (brak możliwości deontycznej, zakaz),

(iii) permisywnością (możliwość deontyczna, dozwolenie) i

(iv) immunitywnością (brak konieczności deontycznej, brak nakazu).

Niniejszy artykuł będzie dotyczył tylko znaczenia obligatywności i signifikatorów tego znaczenia deontycznego. 


\section{Metoda i przedmiot analizy}

Po przeanalizowaniu wszystkich zdań z obu kodeksów zostały z nich wyekscerpowane te, które przenoszą znaczenie obligatywności, a następnie wyróżnione $\mathrm{w}$ nich signifikatory obligatywności. Zdanie rozumiane jest tu jako syntagma ${ }^{3}$ zawierająca jedno orzeczenie (Bańczerowski i in. 1982: 293). W analizowanych tekstach prawnych orzeczenie ma zawsze postać osobowej formy czasownika albo imiennej części mowy (nomen) ze słowem posiłkowym (łącznikiem). Orzeczenia, w których skład wchodzą słowa posiłkowe, traktowane sa jako wyrazy, a nie syntagmy. Pod uwagę brane są tylko zdania główne oraz zdania podrzędne przydawkowe rozwijające, a także te, w których czynność deontyczna, w tym przypadku czynność objęta nakazem, jest wyrażona eksplicytnie. $\mathrm{Z}$ analizy zostały wyłączone zdania, które nie zawierają wyrazu nazywającego czynność deontyczna, nawet jeśli można $\mathrm{z}$ tych zdań, odwołując się do zasad wykładni i interpretacji prawa, a także do innych fragmetów tekstu ustawy lub innych ustaw, wnosić o takich czynnościach, ponieważ takie zdania nie zawierają interesujących nas tutaj signifikatorów znaczenia obligatywności. Czynność deontyczna musi być czynnością wolitywna, czyli podlegająca woli jej wykonawcy, tj. agensa. Tylko taka czynność może być bowiem przedmiotem nakazu. Dlatego na przykład zdanie poniższe nie jest traktowane jako zdanie przenoszące znaczenie obligatywności (nie można bowiem nakazać umowie, by coś określała):

\section{Przykład 1:}

Art. 389. § 1. Umowa, przez która jedna ze stron lub obie zobowiazuja sie do zawarcia oznaczonej umowy (umowa przedwstepna), powinna określać istotne postanowienia.

\section{Signifikatory znaczeń deontycznych}

Analiza korpusu wykazała, że signifikatory obligatywności są liczne i zróżnicowane. Ich szczegółowe zestawienie zawierają tabele umieszczone w dalszej części tekstu. Dla przejrzystości i dokładności opisu zostały zastosowane dwa rodzaje podziału wszystkich występujących w badanych tekstach signifikatorów.

Po pierwsze, signifikatory podzielone są według kategorii semantycznej wyrazu będącego podmiotem w zdaniu, w którym wystapił dany signifikator. Wynika to $\mathrm{z}$ tego, że należy odróżniać zdania w stronie czynnej, w których podmiotem jest agens czynności (np. X powinien zrobić...), od zdań w stronie biernej, w których podmiotem jest patiens czynności (np. X powinien być zrobiony...), a także od zdań, w których podmiotem jest wyraz oznaczający czynność deontyczną albo determinatum signifikatora modalności. To ostatnie dotyczy zdań, w których signifikatorem jest syntagma rzeczownikowoczasownikowa (na przykład ciężar spoczywa). W zdaniach takich podmiotem jest

\footnotetext{
${ }^{3}$ Syntagma, zwana też grupą składniowa, to „dopuszczalne w danym języku wyrażenia, składające się co najmniej z dwu (...) wyrazów” (Bańczerowski i in. 1982, 192).
} 
determinatum (wyraz określany) tej syntagmy (w tym przykładzie: ciężar). W badanym korpusie wystapiły także - choć mniej licznie - zdania, w których podmiotem jest kauzator modalnościowy. Niektóre zdania są bezpodmiotowe, tzn. ich orzeczeniami sa: (i) czasowniki niewłaściwe (np. trzeba, można), lub (ii) formy bezosobowe czasowników osobowych (z zaimkiem się, np. stosuje się).

- kontekst ${ }^{4}$,

Po drugie signifikatory pogrupowane są w następujące kategorie:

- czasownik właściwy aktywny,

- czasownik właściwy pasywny,

- czasownik niewłaściwy,

- przymiotnik,

- rzeczownik,

- syntagma czasownikowo-czasownikowa,

- syntagma czasownikowo-rzeczownikowa,

- syntagma rzeczownikowo-czasownikowa.

Do kategorii „kontekst” zalicza się tutaj te zdania, w których kontekst jest jedynym signifikatorem znaczenia deontycznego. Są to zdania mające formę nazywaną przez prawników „pozornie opisową” (por. Malinowski 2006: 11-12), np.:

Przykład 2:

Art. 410. § 1. Przepisy artykulów poprzedzajacych stosuje się w szczególności do świadczenia nienależnego.

Zdania tego typu poza kontekstem tekstu normatywnego, jakim jest w tym przypadku ustawa, nie przenosiłyby znaczenia deontycznego, a byłyby zdaniami wyłącznie informującymi. Natomiast wystapienie takiego zdania w kontekście tekstu normatywnego sprawia, że przenosi ono takie znaczenie deontyczne. Kontekst dotyczy niewątpliwie wszystkich występujących $\mathrm{w}$ korpusie zdań, które przenoszą znaczenia deontyczne, jednak w pozostałych przypadkach oprócz kontekstu występują też signifikatory inne niż sam kontekst.

Czasowniki można podzielić, opierając się na kategoriach fleksyjnych, na właściwe i niewłaściwe (Saloni i Świdziński 1998: 103). Czasowniki właściwe to „klasa leksemów nie odmieniających się przez przypadek, natomiast mających kategorię fleksyjną osoby”, np. wyrazy pisać, robić, a czasowniki niewłaściwe to „klasa leksemów odmiennych, lecz nie odmieniających się przez przypadek ani przez osobę”, np. należy, trzeba (Saloni, Świdziński 1998: 103). Wyraz powinien traktowany jest tu więc jako czasownik właściwy (specjalnego rodzaju, ponieważ ma szczególne formy fleksyjne i nie posiada bezokolicznika). W związku z tym, że czasowniki niewłaściwe występują tylko

\footnotetext{
${ }^{4}$ Signifikatory obligatywności występują zawsze bez negacji, dlatego też nie zaznacza się tego każdorazowo przy wyróżnionych kategoriach.
} 
w stronie czynnej, nie zachodzi potrzeba rozróżnienia na czasowniki niewłaściwe aktywne i pasywne.

Jak już zaznaczono, wyrażenia, w których skład wchodzi słowo posiłkowe, np. jest zobowiazany, está obligado, traktowane sa jako jeden wyraz. Wyrażenie jest zobowiqzany opisywane jest zatem jako czasownik (strona bierna czasownika zobowiqzuje). Wyrażenie jest obowiazany traktowane jest natomiast jako przymiotnik: we współczesnej polszczyźnie nie istnieje bowiem czasownik obowiazać, którego formą strony biernej byłoby wyrażenie jest obowiazany.

W przypadku syntagmy pierwszy człon jej nazwy odpowiada członowi określanemu, a drugi - określającemu.

\section{Zestawienie tabelaryczne signifikatorów obligatywności}

Tabele, w których zestawiono odpowiadające sobie znaczeniem signifikatory polskie i hiszpańskie, nie uwzględniają różnic w szyku słów i wyrazów. Na przykład dla języka polskiego nie rozróżnia się szyku obowiazany jest jako różnego od szyku jest obowiazany. Wyrażenia te traktowane sa jako ten sam signifikator.

W hiszpańskich formach bezosobowych zapisywana jest - dla przejrzystości - tylko postać se debe BA (objaśnienia skrótów poniżej), bez debe BA-se. Przy poszczególnych signifikatorach podana jest również kategoria partyoratywna, do której należy wyraz określający dany signifikator, np. AGS + debe/deberá + BA. Ponadto w tabelach znajduje się informacja czy dany signifikator występował w korpusie w czasie teraźniejszym (P), czy przyszłym (F).

Objaśnienia skrótów zastosowanych w tabelach:

AGS - agens

AKM - agens kauzatora modalnościowego

BA - bezokolicznik aktywny

$\mathrm{BP}$ - bezokolicznik pasywny

COA - czasownik osobowy aktywny

COP - czasownik osobowy pasywny

(F) - możliwość użycia w czasie przyszłym (futurum)

KM - kauzator modalnościowy

$\mathrm{NEG}$ - negacja

(p) - strona bierna peryfrastyczna

(P) - możliwość użycia w czasie teraźniejszym (praesens)

PTS - patiens

RO - rzeczownik odczasownikowy

(zb) - strona zwrotno-bierna (pasiva con se)

ZD - zdanie podrzędne

* - oznacza signifikatory występujące w korpusie rzadko 
Signifikatory obligatywności w zdaniach, w których podmiotem jest agens czynności deontycznej

Tab. 1. Signifikatory obligatywności $\mathrm{w}$ zdaniach, w których podmiotem jest agens czynności deontycznej.

\begin{tabular}{|c|c|}
\hline Polski & Hiszpański \\
\hline \multicolumn{2}{|l|}{ kontekst } \\
\hline $\mathrm{AGS}+\mathrm{COA}(\mathrm{P} / \mathrm{F})$ & $\mathrm{AGS}+\mathrm{COA}(\mathrm{F})$ \\
\hline \multicolumn{2}{|l|}{ czasownik wlaściwy aktywny } \\
\hline $\mathrm{AGS}+$ powinien $+\mathrm{BA}(\mathrm{P})$ & $\mathrm{AGS}+$ debe/deberá + BA (P/F) \\
\hline- & $\mathrm{AGS}+$ ha/habrá de + BA (P/F) \\
\hline- & $\mathrm{AGS}+$ tiene/tendrá que $+\mathrm{BA}\left(\mathrm{P}^{*} / \mathrm{F}^{*}\right)$ \\
\hline AGS + zobowiązuje się do + RO $\left(\mathrm{P}^{*}\right)$ & - \\
\hline \multicolumn{2}{|l|}{ czasownik wlaściwy pasywny } \\
\hline $\begin{array}{l}\text { AGS }+ \text { jest zobowiazany }+ \text { BA }\left(\mathrm{P}^{*}\right) \\
\text { AGS }+ \text { jest zobowiązany do }+ \text { RO }\left(\mathrm{P}^{*}\right)\end{array}$ & $\begin{array}{l}\text { AGS + está/estará +obligado a }+ \text { BA } \\
(\mathrm{P} / \mathrm{F}) \\
\mathrm{AGS}+\text { está/estará +obligado a }+\mathrm{RO} \\
(\mathrm{P} / \mathrm{F})\end{array}$ \\
\hline - & $\begin{array}{l}\text { AGS }+ \text { queda obligado a }+ \text { BA }(\mathrm{P}) \\
\text { AGS }+ \text { quedará obligado a }+ \text { RO }(\mathrm{F})\end{array}$ \\
\hline - & AGS + se halla obligado a + BA $\left(\mathrm{P}^{*}\right)$ \\
\hline \multicolumn{2}{|l|}{ przymiotnik } \\
\hline $\begin{array}{l}\text { AGS }+ \text { jest obowiązany + BA (P) } \\
\text { AGS }+ \text { jest obowiązany do + RO (P) }\end{array}$ & $\mathrm{AGS}+$ queda sujeto $\mathrm{a}+\mathrm{RO}\left(\mathrm{P}^{*}\right)$ \\
\hline \multicolumn{2}{|l|}{ syntagma czasownikowo-rzeczownikowa } \\
\hline $\begin{array}{l}\text { AGS + ma obowiazek + BA }\left(\mathrm{P}^{*}\right) \\
\text { AGS + ma obowiązek + RO }\left(\mathrm{P}^{*}\right)\end{array}$ & $\begin{array}{l}\text { AGS + tiene/tendrá obligación de }+ \text { BA } \\
(\mathrm{P} / \mathrm{F}) \\
\mathrm{AGS}+\text { tiene/tendrá la obligación }+\mathrm{BA} \\
(\mathrm{P} / \mathrm{F})\end{array}$ \\
\hline - & AGS + tiene el deber de + BA $\left(\mathrm{P}^{*}\right)$ \\
\hline
\end{tabular}

Jak wynika $\mathrm{z}$ tab. 1, w zdaniach, w których agens jest podmiotem, signifikatory obligatywności $\mathrm{w}$ języku hiszpańskim są bardziej zróżnicowane niż $\mathrm{w}$ języku polskim. $\mathrm{W}$ obu językach występują zdania, w których kontekst jest jedynym signifikatorem obligatywności. Ilustrują to następujące przykłady:

Przykład 3:

Art. 359 § 3. Rada Ministrów określa, w drodze rozporzadzenia, wysokość odsetek ustawowych, kierując sie koniecznościa zapewnienia dyscypliny płatniczej i sprawnego przeprowadzania rozliczeń pieniężnych, biorac pod uwage wysokość rynkowych stóp procentowych oraz stóp procentowych Narodowego Banku Polskiego. 


\section{Przykład 4:}

Art. 1124. (...) El Tribunal decretará la resolución que se reclame, a no haber causas justificadas que le autoricen para señalar plazo.

'(...) Sąd nakaże unieważnienie, o które się wnosi, o ile nie będzie uzasadnionych względów pozwalających mu wyznaczyć termin'. ${ }^{5}$

W języku polskim takie zdania występują zarówno w czasie teraźniejszym, jak i przyszłym, natomiast $\mathrm{w}$ języku hiszpańskim tylko w czasie przyszłym. Pozostałe signifikatory w języku polskim, inaczej niż w hiszpańskim, występują tylko w czasie teraźniejszym. Do najczęściej występujących czasowników właściwych należy w języku polskim czasownik powinien, a w języku hiszpańskim czasowniki deber i haber de. Przykładami tych signifikatorów są następujące zdania:

\section{Przykład 5:}

Art. 367. $\S 2$. Jednakże $w$ razie wytoczenia powództwa przez jednego z wierzycieli dlużnik powinien spetnić świadczenie do jego rąk.

\section{Przykład 6:}

Art. 1578. El arrendatario saliente debe permitir al entrante el uso del local y demás medios necesarios para las labores preparatorias del año siguiente (...).

'Ustępujący dzierżawca powinien umożliwić następnemu używanie lokalu i innych środków niezbędnych do prac przygotowawczych do następnego roku (...)'.

\section{Przykład 7:}

Art. 579. (...) Para usar el medianero de este derecho ha de obtener previamente el consentimiento de los demás interesados en la medianería (...)

'(...) Aby sąiad współposiadający mur mógł korzystać z tego prawa, powinien uprzednio uzyskać zgodę pozostałych zainteresowanych (...)'

\footnotetext{
${ }^{5} \mathrm{~W}$ związku z tym, że artykuł dotyczy analizy tekstu pod względem struktury językowej, polskie thumaczenia zdań hiszpańskich - pochodzące od autorki - mają w miarę możliwości odzwierciedlać tę strukturę. Dlatego czasem dosłowności thumaczenia przyznaje się prymat nad poprawnością stylistyczną.

Jeżeli thumaczenie narusza zasady stylistyki polskiej w sposób rażący, podane jest w nawiasie kwadratowym i opatrzone skrótem: [dosł.].

Jeżeli tłumaczenie jest niepoprawne z punktu widzenia gramatyki polskiej, oprócz skrótu 'dosł.' jest ono opatrzone także gwiazdką [*].

$\mathrm{W}$ niektórych przypadkach możliwe jest tylko przybliżone thumaczenie struktury zdania hiszpańskiego. Zaznaczone jest to symbolem [ ].
} 
Jedyny czasownik właściwy pasywny występujący - i to rzadko - w korpusie polskim to czasownik jest zobowiazany. W języku hiszpańskim używane są warianty formy pasywnej czasownika obligar z różnymi słowami posiłkowymi, np.:

\section{Przykład 8:}

Art. 809. \& 1. Ubezpieczyciel zobowiazany jest potwierdzić zawarcie umowy dokumentem ubezpieczenia.

\section{Przykład 9:}

Art. 1555. El arrendatario está obligado: 1. A pagar el precio del arrendamiento en los términos convenidos. (...)

'Wynajmujący jest zobowiązany: 1. uiszczać czynsz w ustalonych terminach. (...)'.

W korpusie polskim należący do kategorii „przymiotnik” signifikator jest obowiqzany występuje znacznie częściej niż signifikator z tej kategorii w języku hiszpańskim, czyli queda sujeto a:

\section{Przykład 10:}

Art. $70^{3} \S 2$. Organizator jest obowiqzany niezwlocznie powiadomić na piśmie uczestników przetargu o jego wyniku albo o zamknięciu przetargu bez dokonania wyboru.

\section{Przykład 11:}

Art. 1101. Quedan sujetos a la indemnización de los daños y perjuicios causados los que en el cumplimiento de sus obligaciones incurrieren en dolo, negligencia o morosidad (...).

'Do [zapłaty] odszkodowania za wyrządzone szkody są obowiązani [dosł. *'są podlegli odszkodowaniu za wyrządzone szkody'] ci, którzy podczas spełniania swoich zobowiązań dopuścili się podstępu, niedbalstwa lub zwłoki (...)'.

W zdaniach, w których podmiotem jest agens czynności deontycznej, signifikatorem w obu językach może być rówież syntagma czasownikowo-rzeczownikowa:

\section{Przykład 12:}

Art. 697. Dzierżawca ma obowiazek dokonywania napraw niezbędnych do zachowania przedmiotu dzierżawy $w$ stanie nie pogorszonym.

\section{Przykład 13:}

Art. 356. El que percibe los frutos tiene la obligación de abonar los gastos hechos por un tercero para su producción, recolección y conservación. 
'Kto pobiera pożytki, ma obowiązek zwrócić nakłady dokonane przez osobę trzecią na ich wytworzenie, zebranie i przechowanie'.

Przykład 14:

Art 1. (...) 7. Los Jueces y Tribunales tienen el deber inexcusable de resolver en todo caso los asuntos de que conozcan, ateniéndose al sistema de fuentes establecido.

'Sędziowie i sądy mają niezbywalny obowiązek każdorazowego orzekania w sprawach, które rozpoznaja, przestrzegając przy tym ustalonego systemu źródeł'.

\section{Signifikatory obligatywności w zdaniach, w których podmiotem jest patiens czynności deontycznej}

Tab. 2. Signifikatory obligatywności w zdaniach, w których podmiotem jest patiens czynności deontycznej

\begin{tabular}{|c|c|}
\hline Polski & Hiszpański \\
\hline \multicolumn{2}{|l|}{ kontekst } \\
\hline $\mathrm{PTS}+u \operatorname{leg} a+\mathrm{RO}(\mathrm{P})$ & $\mathrm{PTS}+\mathrm{COP}(\mathrm{zb})(\mathrm{P} / \mathrm{F})$ \\
\hline $\mathrm{PTS}+\mathrm{COP}\left(\mathrm{F}^{*} / \mathrm{P}^{*}\right)$ & $\mathrm{PTS}+\mathrm{COP}(\mathrm{p})(\mathrm{F})$ \\
\hline $\mathrm{PTS}+\mathrm{ma}+\mathrm{RO}(\mathrm{P})$ & $\mathrm{PTS}+$ tiene/tendrá $+\mathrm{RO}(\mathrm{P} / \mathrm{F})$ \\
\hline- & PTS + será de + RO $\left(\mathrm{F}^{*}\right)$ \\
\hline \multicolumn{2}{|l|}{ czasownik właściwy aktywny } \\
\hline PTS + powinien + BP $(\mathrm{P})$ & $\mathrm{PTS}+$ debe/deberá + BP $(\mathrm{zb}, \mathrm{p})(\mathrm{P} / \mathrm{F})$ \\
\hline- & PTS + ha/habrá de + BP (zb) (P/F) \\
\hline- & $\mathrm{PTS}+$ ha/habrá de + BP (p) $\left(\mathrm{P}^{*} / \mathrm{F}^{*}\right)$ \\
\hline \multicolumn{2}{|l|}{ przymiotnik } \\
\hline $\begin{array}{l}\text { PTS }+\underset{\text { jest }}{\text { koniecznościowy }\left(\mathrm{P}^{*}\right)}+\end{array}$ & $\begin{array}{l}\text { PTS }+ \text { es/será } \\
\text { koniecznościowy }(\mathrm{P} / \mathrm{F})\end{array}$ \\
\hline- & PTS + está sujeto a + RO $\left(\mathrm{F}^{*}\right)$ \\
\hline \multicolumn{2}{|c|}{ syntagma czasownikowo-rzeczownikowa } \\
\hline- & $\begin{array}{l}\text { PTS + tiene/tendrá derecho a }+ \text { BP }(\mathrm{p}) \\
\left(\mathrm{P}^{*} / \mathrm{F}^{*}\right)^{6}\end{array}$ \\
\hline
\end{tabular}

W zdaniach, w których podmiotem jest patiens czynności deontycznej, signifikatorem, podobnie jak w zdaniach, w których podmiotem jest agens, może być sam kontekst. W obu językach takie zdania występowały zarówno w czasie teraźniejszym, jak i przyszłym:

\footnotetext{
${ }^{6}$ Tylko patiens osobowy.
} 


\section{Przykład 15:}

Art. 1020. Spadkobierca, który spadek odrzucit, zostaje wytaczony od dziedziczenia, tak jakby nie dożył otwarcia spadku.

Przykład 16:

Art. 453. Los gastos necesarios se abonan a todo poseedor; (...).

'Nakłady konieczne zwraca się [dosł. 'są zwracane'] każdemu z posiadaczy; (...)'.

Signifikatorami mogą być również te same czasowniki właściwe co w zdaniach, w których podmiotem jest agens czynności deontycznej (powinien, debe, ha de). Signifikatorem w obu językach może być także przymiotnik koniecznościowy. Przymiotniki koniecznościowe np. płatny (wstep, bilet), karalny (postepek) - obok potencjalnych - np. wykonalne (zadanie) zalicza się do szerszej kategorii tzw. przymiotników predyspozycyjnych (Puzynina 1976, 263 264). Przymiotnik koniecznościowy przenosi znaczenie 'taki, który musi być (poddany czynności wyrażonej w jego temacie)', czyli znaczenie obligatywne. Jak zaznacza Puzynina (która pisze tylko o języku polskim), przymiotniki koniecznościowe są rzadkie i ,znaczenie to nigdy nie jest w języku polskim jedyne dla danego przymiotnika" (Puzynina 1976, 264). W języku hiszpańskim przymiotniki takie posiadają zazwyczaj sufiks -ble (przenoszący według gramatyk ,znaczenie bierne i modalne”, RAE 2010: 146). W języku polskim są to sufiksy -alny i $-n y$. Ponieważ znaczenie sufiksów słowotwórczych nie jest regularne, trzeba analizować osobno każdy przypadek. Mówiąc o tego rodzaju przymiotnikach, należy zwrócić uwagę na fakt, iż oprócz tego, że są signifikatorami modalności, nazywają one także samą czynność deontyczną.

Przykładami zdań, w których signifikatorem jest przymiotnik koniecznościowy, są zdania następujące:

\section{Przykład 17:}

Art. 699. Jeżeli termin platności czynszu nie jest $w$ umowie oznaczony, czynsz jest ptatny z dołu w terminie zwyczajowo przyjętym, a w braku takiego zwyczaju pótrocznie z dotu.

\section{Przykład 18:}

Art. 1799. Lo dispuesto en el artículo anterior respecto del juego es aplicable a las apuestas.

'Przepis artykułu poprzedzającego dotyczący gier stosuje się [dosł. 'jest stosowalny'] do zakładów'.

Przymiotnik aplicable w definicji słownikowej posiada dwa znaczenia: „Que se puede o se debe aplicar" '[taki,] który można lub trzeba zastosować' (Maldonado 
González 2000: 132). Jednak w zdaniu powyższym kontekst wskazuje na to, że znaczenie tego wyrazu jest tylko obligatywne: 'taki, który należy zastosować,7.

Omówienia wymaga tutaj również signifikator w postaci syntagmy czasownikoworzeczownikowej tiene derecho, który występuje w korpusie rzadko i tylko w języku hiszpańskim. Np.:

\section{Przykład 19:}

Art. 446. Todo poseedor tiene derecho a ser respetado en su posesión; (...).

'Każdy posiadacz ma prawo do tego, by szanowano stan jego posiadania'.

[dosł.*' ma prawo być szanowanym w swoim posiadaniu'].

Czynnością deontyczną wyrażoną $\mathrm{w}$ tym zdaniu jest respetar 'szanować'. Inne czasowniki, które w C. C. wystapiły w tej konstrukcji (w formie imiesłowów biernych) to igualar 'wynagrodzić', reintegrar 'ts. ', amparar 'chronić'. Są to, jak można zauważyć, nazwy czynności innych osób korzystne dla patiensa. Mimo wystapienia w tym zdaniu syntagmy zawierającej wyraz derecho 'prawo' czynność, o której tu mowa, tj. szanowanie, jest przedmiotem nakazu, a więc objęta jest modalnością obligatywna. Zdanie to mówi, że wszyscy powinni szanować posiadacza. Jak wynika $\mathrm{z}$ analizy podobych zdań, które wystapiły w korpusie, w zdaniach w stronie biernej z podmiotem osobowym zwroty tiene derecho a 'ma prawo do' i debe 'powinien' są synonimiczne - ale jest tak tylko wtedy, jeżeli czasownik oznacza czynność korzystną dla patiensa.

\section{Signifikatory obligatywności w zdaniach, w których podmiotem jest czynność deontyczna}

Tab. 3. Signifikatory obligatywności w zdaniach, w których podmiotem jest czynność deontyczna

\begin{tabular}{|c|c|}
\hline Polski & Hiszpański \\
\hline \multicolumn{2}{|l|}{ kontekst } \\
\hline $\mathrm{RO}+\mathrm{COA}\left(\mathrm{P} / \mathrm{F}^{*}\right)$ & $\mathrm{RO}+\mathrm{COA}\left(\mathrm{F}^{*}\right)$ \\
\hline \multicolumn{2}{|c|}{ czasownik właściwy aktywny } \\
\hline- & $\mathrm{RO}+$ incumbe a $\left(\mathrm{P}^{*}\right)$ \\
\hline - & $\mathrm{RO}+$ corresponde/corresponderá a $(\mathrm{P} / \mathrm{F})$ \\
\hline- & se necesita + BA $(P)$ \\
\hline- & se necesita + RO (P) \\
\hline - & se necesita + ZD $(\mathrm{P})$ \\
\hline- & se requiere $+\mathrm{ZD}(\mathrm{P})$ \\
\hline - & se requerirá $+\mathrm{RO}(\mathrm{F})$ \\
\hline
\end{tabular}

\footnotetext{
${ }^{7}$ Warto zaznaczyć, że jeden ze słowników hiszpańsko-polskich tłumaczy aplicable jako 'dający się zastosować' (Wawrzkowicz, Hiszpański 1982: 70).
} 
Comparative Legilinguistics 13/2013

\begin{tabular}{|c|c|}
\hline \multicolumn{2}{|l|}{ czasownik właściwy pasywny } \\
\hline jest wymagany + RO (P) & - \\
\hline \multicolumn{2}{|l|}{ przymiotnik } \\
\hline $\begin{array}{l}\text { jest potrzebny + RO (P) } \\
\text { jest konieczny }+ \text { RO }(\mathrm{P})\end{array}$ & $\begin{array}{l}\text { es/será preciso + BA }(\mathrm{P} / \mathrm{F}) \\
\text { es preciso }+\mathrm{ZD}(\mathrm{P})^{*} \\
\text { será necesario + RO }(\mathrm{F})^{*} \\
\text { es indispensable + ZD }(\mathrm{P})\end{array}$ \\
\hline \multicolumn{2}{|l|}{ rzeczownik } \\
\hline- & $\mathrm{RO}+$ quedará a cargo de $\left(\mathrm{F}^{*}\right)$ \\
\hline- & son requisitos $+\mathrm{ZD}\left(\mathrm{P}^{*}\right)$ \\
\hline \multicolumn{2}{|c|}{ syntagma czasownikowo-czasownikowa } \\
\hline $\mathrm{RO}+$ powinien nastapić $(\mathrm{P})$ & - \\
\hline
\end{tabular}

Również $\mathrm{w}$ tej grupie signifikatory $\mathrm{w}$ języku hiszpańskim są liczniejsze i bardziej zróżnicowane. W obu językach signifikatorem może być sam kontekst (w języku hiszpańskim takie zdania występują tylko w czasie przyszłym). Signifikator w postaci czasownika właściwego aktywnego występuje tylko w języku hiszpańskim (w kilku wariantach), np.:

Przykład 20:

Art. 1750. (...) En caso de duda, incumbe la prueba al comodatario.

'(...) W przypadku wątpliwym dowód ciąży na biorącym [do używania]'.

\section{Przykład 21:}

Art. 434. La buena fe se presume siempre, y al que afirma la mala fe de un poseedor corresponde la prueba.

'Domniemywa się zawsze dobrą wiarę, a na tym, kto twierdzi, że posiadacz był w złej wierze, spoczywa obowiazek udowodnienia tego [dosł. 'temu, kto twierdzi (...), przypada udowodnienie']'.

Czasownik właściwy pasywny jest natomiast używany tylko w języku polskim (odnotowano tylko jeden rodzaj czasownika należący do tej kategorii - jest wymagany), np.:

Przykład 22:

Art. 647. \$2. Do zawarcia przez wykonawce umowy o roboty budowlane $z$ podwykonawca jest wymagana zgoda inwestora.

Signifikatorami w tej grupie mogą być także przymiotniki, które wystapiły w obu badanych językach, np.: 


\section{Przykład 23:}

Art. 517. (...) Do przeniesienia własności dokumentu potrzebne jest jego wydanie.

\section{Przykład 24:}

Art. 831. $\S 1^{1}$. W razie zawarcia umowy ubezpieczenia na cudzy rachunek do wykonywania uprawnień, o których mowa w paragrafie poprzedzajacym, konieczna jest uprzednia zgoda ubezpieczonego; (...).

\section{Przykład 25:}

Art. 716. (...) En todos los casos de este artículo será siempre necesaria la presencia de dos testigos idóneos.

'(...) We wszystkich wypadkach przewidzianych w tym artykule konieczna jest [dosł. 'konieczna będzie'] obecność dwóch świadków'.

\section{Przykład 26:}

Art. 1204. Para que una obligación quede extinguida por otra que la sustituya, es preciso que así se declare terminantemente, o (...).

'Aby zobowiązanie zostało umorzone przez inne, zastępujące je, należy to wyraźnie oświadczyć [dosł. 'jest konieczne, aby zostało to wyraźnie oświadczone] albo (...)'.

\section{Przykład 27:}

Art. 1875. (...), es indispensable, para que la hipoteca quede válidamente constituida, que el documento en que se constituya sea inscrito en el Registro de la propiedad.

'(...) w celu ważnego ustanowienia hipoteki dokument, w którym jest ustanawiana, powinien być wpisany [dosł. 'jest nieodzowne, aby dokument (...) był wpisany'] do Rejestru Własności'.

Tylko w tej grupie zdań - w których podmiotem jest czynność deontyczna w rzadkich przypadkach w języku hiszpańskim signifikatorem jest rzeczownik, np.:

\section{Przykład 28:}

Art. 1857. Son requisitos esenciales de los contratos de prenda e hipoteca: 1. Que se constituya para asegurar el cumplimiento de una obligación principal.

'Zasadniczymi wymogami przy umowach zastawu i hipoteki są: 1. ustanawianie ich [dosł. 'by ustanawiać je'] w celu zabezpieczenia spełnienia zobowiązania głównego'. 2 (...). 


\section{Przykład 29:}

Art. 867. Cuando el testador legare una cosa empeñada o hipotecada para la seguridad de alguna deuda exigible, el pago de ésta quedará a cargo del heredero. 'Jeżeli spadkodawca zapisuje rzecz obciążoną zastawem albo hipoteką w celu zabezpieczenia wymagalnego długu, obowiązek zapłaty za nią spoczywa na [dosł. 'zapłata za nią pozostanie ciężarem'] spadkobiercy'.

W przykładzie 29 „quedará” nie jest wyrazem, lecz słowem posiłkowym (łącznikiem).

$\mathrm{W}$ języku polskim w tej grupie zdań signifikatorem może być również syntagma czasownikowo-czasownikowa, np.:

\section{Przykład 30:}

Art. 363. \&1. Naprawienie szkody powinno nastapić, wedlug wyboru poszkodowanego, bądź przez przywrócenie stanu poprzedniego, bądź przez zaptatę odpowiedniej sumy pieniężnej.

\section{Signifikatory obligatywności w zdaniach, w których podmiotem jest determinatum signifikatora}

Tab. 4. Signifikatory obligatywności w zdaniach, w których podmiotem jest determinatum signifikatora

\begin{tabular}{|l|l|}
\hline Polski & Hiszpański \\
\hline syntagma rzeczownikowo-czasownikowa \\
\hline $\begin{array}{l}\text { ciężar + RO + spoczywa na }\left(\mathrm{P}^{*}\right) \\
\text { obowiązek + RO + obciąża }\left(\mathrm{P}^{*}\right)\end{array}$ & $\begin{array}{l}\text { la obligación de }+\mathrm{BA}+\text { corresponde a } \\
(\mathrm{P})\end{array}$ \\
\hline- & surge la obligación de + BA $\left(\mathrm{P}^{*}\right)$ \\
\hline
\end{tabular}

Determinatum signifikatora może być podmiotem tylko w zdaniach, w których signifikatorem jest syntagma rzeczownikowo-czasownikowa. W języku polskim zdania takie były rzadkie, np.:

Przykład 31:

Art. $385^{I}$. 4. Ciężar dowodu, że postanowienie zostało uzgodnione indywidualnie, spoczywa na tym, kto się na to powohuje.

Przykład 32:

Art. 289. $§ 1 . \quad W$ braku odmiennej umowy obowiqzek utrzymywania urządzeń potrzebnych do wykonywania służebności gruntowej obciqża właściciela nieruchomości wtadnacej. 
W języku hiszpańskim wystapienie tego rodzaju signifikatorów ilustrują następujące przykłady:

\section{Przykład 33:}

Art. 1645. La obligación de pagar el laudemio corresponde al adquirente, salvo pacto en contrario.

Obowiązek zapłacenia laudemium obciąża nabywcę [dosł. 'przypada nabywcy'], o ile nie uzgodniono inaczej’.

\section{Przykład 34:}

Art. 1895. Cuando se recibe alguna cosa que no habia derecho a cobrar, y que por error ha sido indebidamente entregada, surge la obligación de restituirla.

'Jeżeli ktoś otrzymał rzecz, której nie miał prawa przyjać, a która została przekazana mu omyłkowo, powinien ją zwrócić [dosł. 'powstaje obowiązek zwrócenia jej']'.

\section{Signifikatory obligatywności w zdaniach, w których podmiotem jest kauzator modalnościowy}

Tab. 5. Signifikatory obligatywności w zdaniach, w których podmiotem jest kauzator modalnościowy.

\begin{tabular}{|l|l|}
\hline Polski & Hiszpański \\
\hline czasownik właściwy aktywny & $\mathrm{KM}+$ obliga a $+\mathrm{RO}(\mathrm{P})$ \\
\hline- & $\mathrm{KM}+$ requiere/requerirá $+\mathrm{RO}(\mathrm{P} / \mathrm{F})$ \\
\hline $\mathrm{KM}+$ wymaga $+\mathrm{RO}(\mathrm{P})$ &
\end{tabular}

W celu opisu pewnego rodzaju zdań konieczne było wprowadzenie nowego pojęcia na wyraz denotujący fakt (może być on czynnością, stanem itp.), który powoduje powstanie lub ustanie obowiązku. Taki wyraz nazywany jest tu kauzatorem modalnościowym. Przykładem może być zdanie następujące, w którym podmiotem i kauzatorem modalnościowym jest wyraz rescisión 'rozwiązanie':

Przykład 35:

Art. 1295. La rescisión obliga a la devolución de las cosas que fueron objeto del contrato con sus frutos, $y$ del precio con sus intereses; (...)

'Rozwiązanie [umowy] zobowiązuje do zwrotu rzeczy będacych jej przedmiotami wraz z ich pożytkami oraz ceny z odsetkami; (...)'. 


\section{Signifikatory obligatywności $w$ zdaniach, $w$ których podmiotem jest agens kauzatora modalnościowego}

Tab. 6. Signifikatory obligatywności w zdaniach, w których podmiotem jest agens kauzatora modalnościowego

\begin{tabular}{|c|c|}
\hline Polski & Hiszpański \\
\hline \multicolumn{2}{|c|}{ czasownik właściwy aktywny } \\
\hline - & $\mathrm{AKM}+$ necesita/necesitará + RO (P/F) \\
\hline
\end{tabular}

Ponieważ kauzator modalnościowy może być czynnością, w niektórych przypadkach można mówić o agensie tej czynności, czyli agensie kauzatora modalnościowego. Istnieją zdania, w których to właśnie on jest podmiotem, jak na przykład w artykule poniższym:

Przykład 36:

Art. 443. Los menores y los incapacitados (...) necesitan de la asistencia de sus representantes legítimos para usar de los derechos que de la posesión nazcan a su favor.

'Małoletnim i ubezwłasnowolnionym (...) do korzystania z praw, które wynikają na ich korzyść z posiadania, potrzebna jest im pomoc [dosł. 'Małoletni i ubezwłasnowolnieni (...) potrzebują pomocy’] ich przedstawicieli ustawowych'.

Pomoc przedstawicieli jest czynnością nakazaną, gdyż jest wymagana do tego, aby nieletni i ubezwłasnowolnieni mogli korzystać z określonych praw. Kauzatorem modalności obligatywnej jest tu korzystanie z praw (zaistnienie tego korzystania w przyszłości - sprawia, że pomoc przedstawicieli jest wymagana). Nieletni i ubezwłasnowolnieni są agensami korzystania. Wyrazy denotujące nieletnich i ubezwłasnowolnionych są w tym zdaniu podmiotem (szeregowym).

\section{Signifikatory obligatywności w zdaniach bezpodmiotowych}

Tab. 7. Signifikatory obligatywności w zdaniach bezpodmiotowych

\begin{tabular}{|l|l|}
\hline Polski & Hiszpański \\
\hline kontekst & $\mathrm{COA}+$ se $(\mathrm{P} / \mathrm{F})$ \\
\hline COA $(\mathrm{P})+$ się & \\
\hline czasownik wlaściwy aktywny & se debe/se deberá $+\mathrm{BA}(\mathrm{P} / \mathrm{F})$ \\
\hline- & - \\
\hline czasownik niewlaściwy & - \\
\hline należy + BA $(\mathrm{P})$ &
\end{tabular}


W zdaniach bezpodmiotowych nie występowało duże zróżnicowanie signifikatorów. Przykładami ilustrującymi signifikator kontekst w zdaniach bezpodmiotowych są zdania następujące:

\section{Przykład 37:}

Art. 410. § 1. Przepisy artykułów poprzedzających stosuje się w szczególności do świadczenia nienależnego.

\section{Przykład 38:}

Art. 1109. (...) En los negocios comerciales se estará a lo que dispone el Código de Comercio.

'(...) W stosunkach handlowych stosuje się przepisy [dosł. **będzie się przy przepisach'] Kodeksu handlowego'.

W zdaniach bezpodmiotowych w języku hiszpańskim signifikatorem może być czasownik aktywny, choć w korpusie wystapił tylko jeden rodzaj takiego czasownika, mianowicie se debe, np.

\section{Przykład 39:}

Art. 1267. (...) Para calificar la intimidación debe atenderse a la edad y a la condición de la persona.

'Przy ocenie, czy miała miejsce groźba, należy brać pod uwagę wiek i stan osoby'

W języku polskim można odnotować wystapienie czasownika niewłaściwego należy:

\section{Przykład 40:}

Art. $7^{1}$ \& 2. W ogloszeniu aukcji albo przetargu należy określić czas, miejsce, przedmiot oraz warunki aukcji albo przetargu albo wskazać sposób udostepnienia tych warunków.

\section{Wnioski końcowe}

Jak zostało to zilustrowane w powyższych tabelach, signifikatory obligatywności, które występują w badanym korpusie, są liczne i zróżnicowane. Daje się zauważyć, że w języku hiszpańskim zachodzi większe zróżnicowanie signifikatorów niż w języku polskim. Dodatkowo wpływa na to fakt, że wiele signifikatorów w języku hiszpańskim występuje zarówno w czasie teraźniejszym, jak i przyszłym, nie zmieniając przy tym swojego znaczenia. Oznacza to, że - o ile nie stoi temu na przeszkodzie złożona struktura zdania - formę czasu można zmienić, nie zmieniając przy tym znaczenia zdania. $\mathrm{W}$ języku polskim również stosuje się czas przyszły, jednak w polskim Kodeksie cywilnym dominuje użycie czasu teraźniejszego. Czas przyszły, inaczej niż w C.C., 
występuje jedynie w tych zdaniach, w których jedynym signifikatorem znaczeń deontycznych jest kontekst. Można również zaobserwować, że jeżeli w C.C. signifikatorem w zdaniu jest tylko kontekst, to zdanie takie najczęściej jest w czasie przyszłym.

Ze zróżnicowania signifikatorów w obrębie jednego znaczenia deontycznego, w tym przypadku obligatywności, wynika ich synonimia. Jest to zjawisko niepożądane w języku prawa. U niespecjalisty może budzić bowiem wątpliwości co do tego, czy różne signifikatory przenoszą to samo znaczenie deontyczne. Podobne wątpliwości może budzić naprzemienne użycie czasu teraźniejszego i przyszłego. Jednym z wyrazistszych przykładów synonimii signifikatorów są signifikatory obligatywności użyte w zdaniach zawartych w trzech różnych artykułach C. C. mówiących o czynności colacionar, czyli 'dołączać do masy spadkowej':

\section{Przykład 41:}

Art. 1038. Cuando los nietos sucedan al abuelo en representación del padre, concurriendo con sus tíos o primos, colacionarán todo lo que debiera colacionar el padre si viviera, aunque no lo hayan heredado.

'Jeżeli wnuki dziedziczą po dziadku w zastępstwie rodzica, wraz z wujostwem lub kuzynami, dołączaja [dosł. 'dołączą'] do masy spadkowej to, co powinien byłby dołączyć rodzic, gdyby żył, nawet jeśli tego nie odziedziczyli’.

\section{Przykład 42:}

Art. 1040. (...); pero, si hubieren sido hechas por el padre conjuntamente a los dos, el hijo estará obligado a colacionar la mitad de la cosa donada.

'(...); jeżeli jednak rodzic dokonał [darowizny] na rzecz ich dwojga łącznie, dziecko jest [dosł. 'będzie] obowiązane dolączyć do masy spadkowej połowę darowanej rzeczy'.

\section{Przykład 43:}

Art. 1043. Serán colacionables las cantidades satisfechas por el padre para redimir a sus hijos de la suerte de soldado, pagar sus deudas, conseguirles un titulo de honor y otros gastos análogos.

'Dołączeniu do masy spadkowej podlegają [dosł. *'będą dołączalne do masy spadkowej'] nakłady poniesione przez rodzica na wykupienie dzieci od służby wojskowej, spłacenie ich długów, wystaranie się dla nich o tytuł honorowy i inne podobne wydatki'.

W art. 1038 signifikatorem jest kontekst, w art. 1040 czasownik właściwy pasywny estará obligado, a w art. 1043 przymiotnik serán colacionables. Wszystkie powyższe zdania wystapiły w czasie przyszłym.

W języku polskim użycie synonimicznych sygnifikatorów zdarza się nawet w jednym zdaniu złożonym, na przykład: 


\section{Przykład 44:}

Art. 608. § 1. Jeżeli w umowie zastrzeżono, że wytworzenie zamówionych rzeczy ma nastapić z surowców określonego gatunku lub pochodzenia, dostawca powinien zawiadomić odbiorce o ich przygotowaniu do produkcji i jest obowiqzany zezwolić odbiorcy na sprawdzenie ich jakości. 


\section{Bibliografia}

Bańczerowski, Jerzy. 2008. Wyraz w ujęciu morfologiczno-typologicznym. [W:] Językoznawstwo historyczne i typologiczne. W 100-lecie urodzin Profesora Tadeusza Milewskiego, red. Leszek Bednarczuk, Wojciech Smoczyński i Maria Wojtyła-Świerzowska, 233-260. Kraków: Polska Akademia Umiejętności.

Lyons, John. 1989. Semantyka. T. I-II. Przeł. A. Weinsberg. Warszawa: Państwowe Wydawnictwo Naukowe [Semantics. Cambridge: Cambridge University Press, 1977].

Maldonado González, Concepción, red. 2000. Clave. Diccionario de uso del español actual. Madrid: Ediciones SM.

Malinowski, Andrzej. 2006. Redagowanie tekstu prawnego. Wybrane wskazania logicznojezykowe. Warszawa: Wydawnictwo Prawnicze LexisNexis.

Nowak, Joanna. 2011. Modalność deontyczna $w$ języku prawa na przyktadzie polskiego i hiszpańskiego kodeksu cywilnego. Praca doktorska. Uniwersytet im. Adama Mickiewicza, http://hdl. handle. net/10593/1002. (data dostępu 15 grudnia 2012).

Palmer, Frank. R. 1998. Mood and modality. Cambridge: University Press.

Portner, Paul. 2009. Modality. Oxford: University Press.

Puzynina, Jadwiga. 1976. „Z problematyki opisu słowotwórczego przymiotników dewerbalnych”. [W:] Semantyka tekstu i jezzka, red. Maria R. Mayenowa, 257-267. Wrocław-WarszawaKraków-Gdańsk: Zakład Narodowy imienia Ossolińskich. Wydawnictwo Polskiej Akademii Nauk.

RAE (Real Academia Española) 2010. Nueva gramática de la lengua española. Manual. Madrid: Espasa Libros.

Rytel, Danuta. 1982. Leksykalne środki wyrażania modalności $w$ języku czeskim $i$ polskim. Wrocław-Warszawa-Kraków-Gdańsk-Łódź: Zakład Narodowy im. Ossolińskich. Wydawnictwo Polskiej Akademii Nauk.

Saloni, Zygmunt i Marek Świdziński. 1998. Składnia wspótczesnego języka polskiego. Warszawa: Wydawnictwo Naukowe PWN.

Wawrzkowicz, S., K. Hiszpański. 1982. Podręczny stownik hiszpańsko-polski. Warszawa: Wiedza Powszechna.

Wróblewski, Bronisław. 1948. Język prawny i prawniczy. Kraków: Nakł. Polskiej Akademii Umiejętności.

\section{Korpus badanych tekstów}

Kodeks cywilny, ustawa z 23 kwietnia 1964 roku (Dz. U. Nr 16, poz. 93 ze zmianami). Tekst według: Kodeks cywilny. Kodeks rodzinny i opiekuńczy. Stan prawny na 1 września 2008 $r$. Warszawa: Wolters Kluwer Polska, 2008.

Código civil (hiszp. 'Kodeks cywilny') - Real Decreto (dekret królewski) z 24. 07. 1889 r. (ze zmianami). Tekstwedług: Código civil. Edición actualizada septiembre de 2008, red. José Carlos Erdozain López, Rodrigo Bercovitz Rodríguez-Cano. Madrid: Tecnos, 2008. 